\title{
E-Service Quality dan E-Promotion Terhadap Keputusan Pembelian Konsumen pada Website Traveloka.com
}

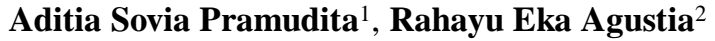 \\ Prodi D4 Logistik Bisnis, Politeknik Pos Indonesia ${ }^{1}$ \\ email: aditiasovia@poltekpos.ac.id ${ }^{1}$ \\ Prodi D4 Logistik Bisnis, Politeknik Pos Indonesia ${ }^{2}$ \\ email : -
}

\begin{abstract}
E-Commerce has a very high growth rate which the needs of quickly and precisely are the main target in the e-commerce business. This study aims to determine how consumers respond to the implementation of e-service quality website, e-promotion website which leads into consumer purchasing decisions at Traveloka using a descriptive quantitative design with data collection techniques through a questionnaire. The method used in this research is descriptive analysis and multiple linear regression analysis. The results show that the effect of website e-service quality and website e-promotion on service purchasing decisions at Traveloka is positive and significant. The influence of e-service quality website and e-promotion website on purchasing decisions at Traveloka is 23\%. While the rest is influenced by variables not included in this study.
\end{abstract}

Keywords: e-service quality website, e-promotion website, purchase decision making process, online travel agent.

\begin{abstract}
Abstrak
E-Commerce saat ini memiliki tingkat pertumbuhan yang sangat tinggi dimana kebutuhan yang didapatkan secara cepat dan tepat menjadi target utama bagi dunia e-commerce. Penelitian ini bertujuan untuk mengetahui bagaimana tanggapan konsumen mengenai pelaksanaan $e$-service quality website, e-promotion website dan keputusan pembelian konsumen di Traveloka, serta mengetahui seberapa besar pengaruh e-service quality website dan e-promotion website terhadap keputusan pembelian di Traveloka. Penelitian ini menggunakan rancangan kuantitatif deskriptif dengan teknik pengumpulan data melalui kuesioner. Metode yang digunakan dalam penelitian adalah analisis deskriptif dan analisis regresi linear berganda. Hasil penelitian menunjukkan bahwa pengaruh antara e-service quality website dan e-promotion website terhadap keputusan pembelian layanan di Traveloka adalah positif dan signifikan. Besar pengaruh e-service quality website dan e-promotion website terhadap keputusan pembelian di Traveloka adalah $23 \%$. Sedangkan sisanya dipengaruhi oleh variabel yang tidak termasuk dalam penelitian ini.
\end{abstract}

Kata Kunci: e-service quality website, e-promotion website, purchase decision making process, online travel agent.

\section{PENDAHULUAN}

Perkembangan ilmu pengetahuan dan teknologi merupakan hal yang tidak dapat dihindari oleh setiap negara di dunia, maka informasi bisa diketahui dengan cepat sehingga pengguna dapat mengakses dengan mudah untuk mendapatkan informasi yang dibutuhkan Penggunaan internet berkembang pesat di dunia, hal ini dibuktikan 
berdasarkan digital 2020 yang dilansir oleh we are social yang mengungkapkan bahwa pengguna internet di seluruh dunia telah mencapai angka 4,5 milyar orang. Angka ini menunjukkan bahwa pengguna internet telah mencapai lebih dari $60 \%$ penduduk dunia. Berikut merupakan data penggunaan internet dunia.

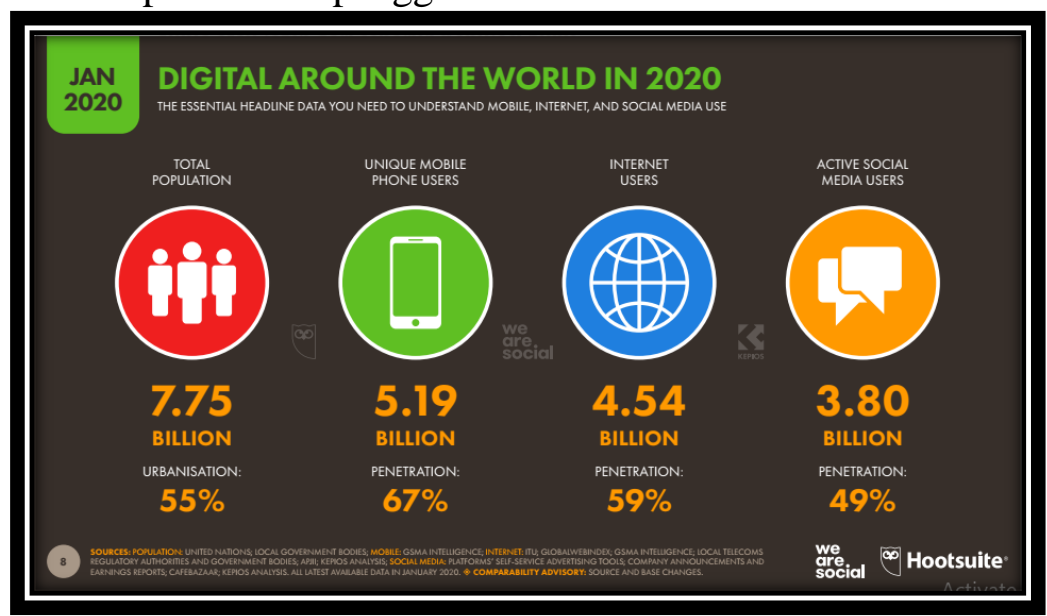

Gambar 1 Penggunaan Internet Dunia 2020

Sumber: We Are Social and Hootsuite, 2020

Dari data digital 2020 yang dilansir oleh we are social tersebut disebutkan juga mengenai informasi tentang Indonesia yang menunjukkan bahwa penetrasi pengguna internet di Indonesia memang terbilang masih jauh dari cakupan maksimal. Sampai tahun 2020 penetrasi internet di Indonesia masih berada di angka 64\% dengan total pengakses sebesar 174 juta orang. Berikut merupakan data penetrasi pengguna internet dunia 2020.

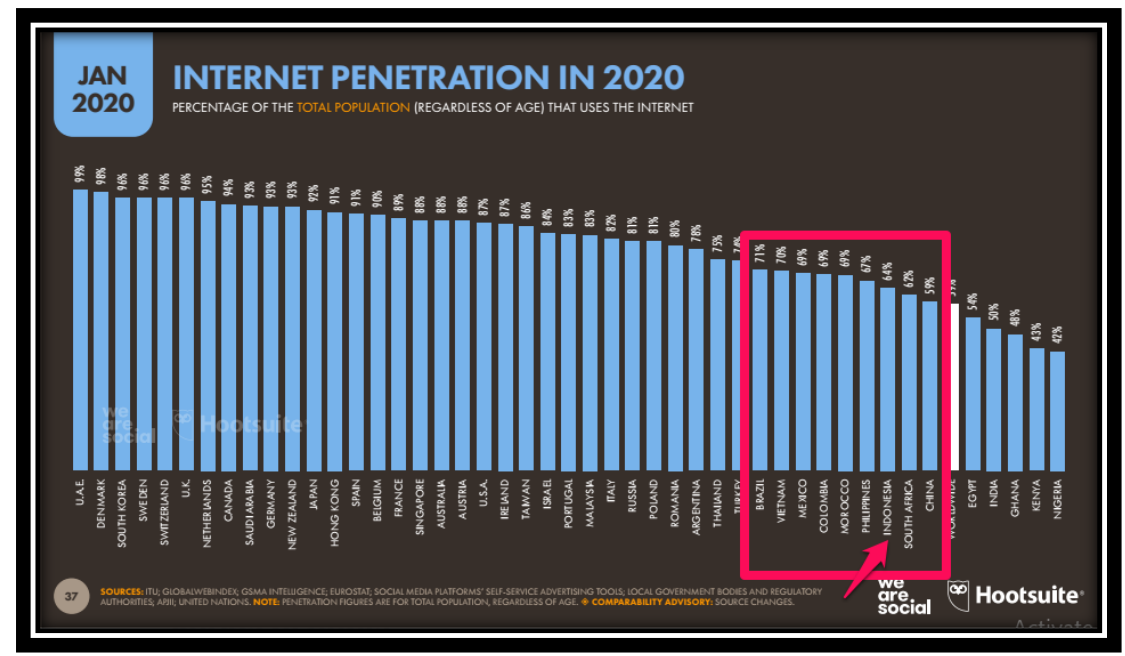

Gambar 2 Data Penetrasi Internet Dunia 2020

Sumber: We Are Social and Hootsuite, 2020 
Perkembangan ilmu pengetahuan beriringan dengan perkembangan teknologi yang mengakibatkan segala sesuatu bisa dilakukan secara online salah satunya yaitu perdagangan berbasis elektronik (e-commerce). Menurut Hari Widowati (2019), Lembaga Riset asal Inggris, Merchant Machine, merilis daftar sepuluh negara dengan pertumbuhan e-commerce tercepat didunia. Indonesia merupakan negara dengan pertumbuhan $e$-commerce tercepat di dunia dengan besar pertumbuhan $78 \%$ pada tahun 2018.

Fenomena trend saat ini banyak masyarakat berbelanja online dengan berbagai produk dipasarkan pada platform e-commerce seperti berbelanja pakaian, makanan, aksesoris, peralatan rumah tangga dan kebutuhan sehari-hari lainnya. Berdasarkan riset consumer barometer yang diadakan oleh google bekerja sama dengan Taylor Nelson Sofres (TNS) dalam Hildha Aprilia (2018), mengungkapkan bahwa dalam melakukan pembelian online, $24 \%$ orang Indonesia terakhir kali yang dibelinya adalah tiket pesawat.

Menurut comscore (2015) dalam Penia Anggraeni dan Putu Nina Madiawati (2016), sejak didirikan pada Maret 2012 hingga Juli 2013, Traveloka menjadi situs travel agent yang tercepat, termurah dan terlengkap dan berhasil menyandang status sebagai situs pencarian tiket pesawat terbaik di Indonesia. Hal ini menunjukan bahwa online travel agent memiliki peluang yang cukup besar untuk berkembang. Salah satu perusahaan online travel agent saat ini yaitu Traveloka.

Menurut Lutfi Hendriyati (2019), online travel agent adalah salah satu produk kemajuan jaman yang sedang booming saat ini, serta merubah peta pemesanan kamar yang dahulunya direct atau go show beralih menggunakan online travel agent (Pramudita, 2019). Online travel agent dalam kegiatan distribution channel sangat memudahkan dalam menjual produk kepada konsumen, cukup dengan membuat website kemudian memasukkan produk-produk menarik dan konsumen akan mudah dan aktif mencari produk-produk yang diinginkannya. Dengan menggunakan media elektronik ini konsumen akan langsung berhubungan dengan supplier tanpa harus melakukan komunikasi dengan media perantara. Sehingga memudahkan konsumen untuk bertanya-tanya mengenai informasi seputar apa yang berkaitan dengan tujuan wisatanya baik itu mengenai akomodasi ataupun harga.

Berdasarkan penelitian SimilarWeb, adapun competitor dari Traveloka adalah Tiket.com, pegipegi, Nusatrip dan Airyroom yang menjalankan usaha yang sama dengan Traveloka. Berikut merupakan analisis dari situs SimilarWeb yang menyatakan perbandingan peringkat atau ranking dari seberapa popular suatu website dibandingkan dengan website lainnya dalam industri yang sejenis.

Tabel 1 Traffic Rank Global dan Country Website Travel Agent

\begin{tabular}{|c|c|c|c|}
\hline No & $\begin{array}{c}\text { Nama Website } \\
\text { Online Travel Agent }\end{array}$ & $\begin{array}{c}\text { Rank Global } \\
\text { (Worldwide) }\end{array}$ & $\begin{array}{c}\text { Rank Country } \\
\text { (Indonesia) }\end{array}$ \\
\hline 1 & Traveloka & 5,187 & 124 \\
\hline 2 & Tiket.com & 12,784 & 228 \\
\hline 3 & Pegipegi & 38,382 & 802 \\
\hline 4 & Nusatrip.com & 45,247 & 1,188 \\
\hline
\end{tabular}




\begin{tabular}{|c|c|c|c|}
\hline 5 & Airyrooms.com & 90,265 & 1,985 \\
\hline
\end{tabular}

Sumber: SimilarWeb, 2020

Dari tabel di atas dapat disimpulkan bahwa Traveloka menempati urutan yang paling unggul diantara para pesaingnya yaitu dengan global rank 5.187 dan country rank 124. Dengan demikian Traveloka mempunyai citra yang cukup baik dari pelanggan. Berikut merupakan data persentase pengunjung dari beberapa negara yang mengakses situs Traveloka.

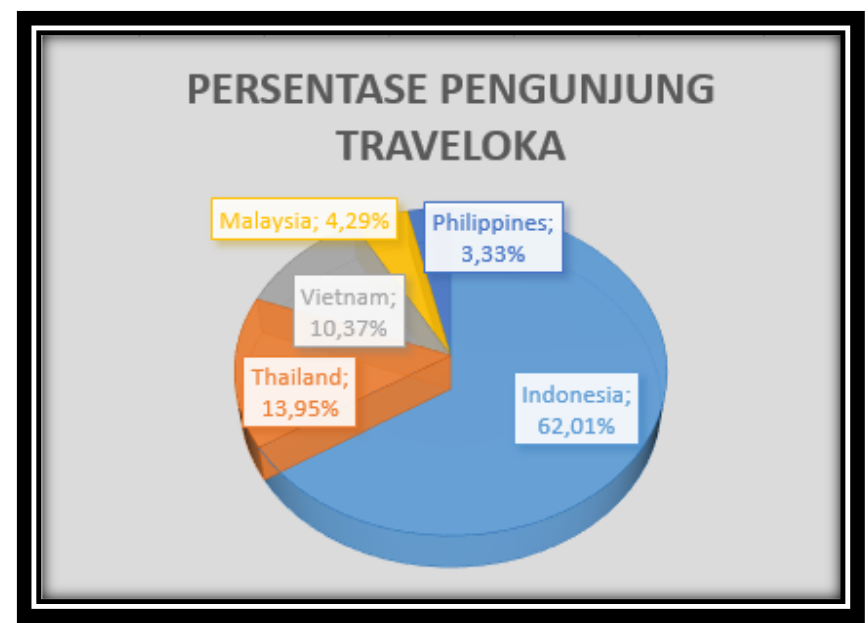

Gambar 3 Data Persentase Pengunjung Traveloka, Maret 2020

Sumber: SimilarWeb, 2020

Pada diagram diatas menunjukkan bahwa pengunjung situs Traveloka paling banyak terdapat di Indonesia dengan persentase 62,01\% dikarenakan Traveloka adalah penyedia jasa akses pemesanan online tiket pesawat, kereta api dan hotel secara online difokuskan pada wilayah Indonesia, sedangkan ada beberapa negara lainnya yang menggunakan aplikasi Traveloka untuk pemesanan tiket secara online tapi tidak terlalu signifikan dalam penggunaannya.

Kemunculan trend digital yang memudahkan pengguna dalam melakukan perjalanan justru menjadi persaingan tersendiri bagi para pengusaha sehingga banyak muncul perusahaan yang sejenis dengan ciri khas yang berbeda-beda yaitu dengan cara menawarkan berbagai promosi sehingga menjadi daya tarik sendiri untuk para pelanggan (Pramudita, Yanuar, \& Hilman, 2019). Hal inilah menjadi tantangan tersendiri bagi Traveloka untuk bisa selalu membuat hal baru dalam meningkatkan profit dan citra baik dari para pelanggannya.

Dari data ini dapat dilihat bahwa Traveloka unggul akan tetapi Traveloka mengalami penurunan jumlah pengunjung dari tahun 2019. Berikut grafik pengunjung situs Traveloka. 


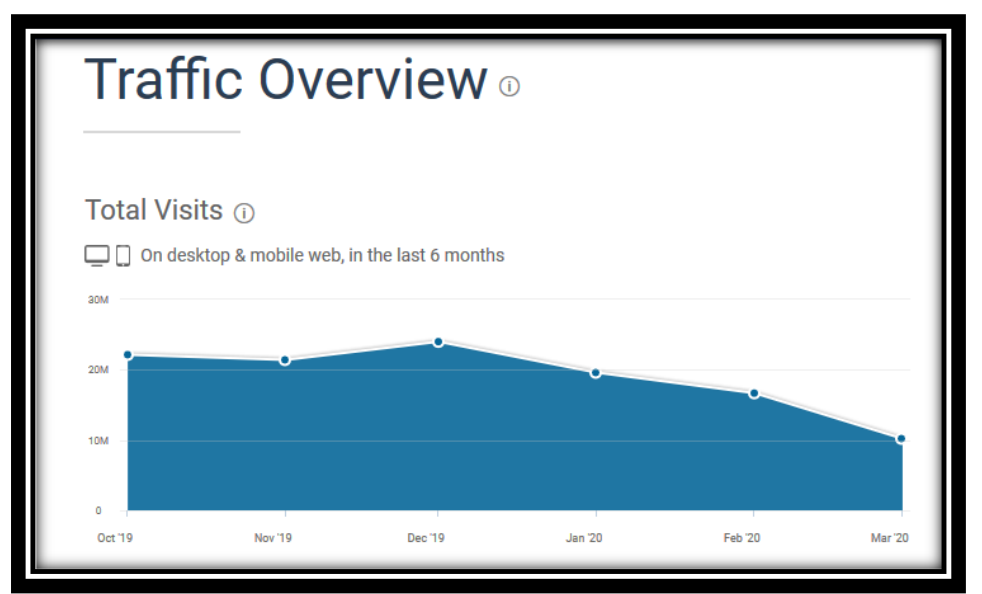

Gambar 4 Data Grafik Pengunjung Situs Traveloka Oktober 2019 - Maret 2020 Sumber: SimilarWeb, 2020

Dari gambar diatas dapat dilihat bahwa penurunan jumlah pengunjung mulai terjadi pada awal Januari 2020 dan berlanjut sampai Maret 2020. Perdagangan jual beli secara online atau daring ini tidak terlepas dari beberapa keluhan yang dilakukan oleh para konsumen atau pelanggan. Hal inilah menjadi catatan tersendiri bagi perusahaan dalam mengembangkan kualitas perusahaan sehingga selalu mendapatkan citra baik dari para pelanggannya.

\section{METODE PENELITIAN}

Jenis penelitian yang digunakan adalah penelitian asosiatif/korelasional dengan pendekatan kuantitatif. Penelitian asosiatif/korelasional merupakan penelitian yang bertujuan untuk mengetahui pengaruh ataupun juga hubungan antara dua variabel atau lebih dengan bantuan regresi linear berganda. Sedangkan pendekatan yang digunakan adalah pendekatan kuantitatif. Pendekatan ini digunakan untuk meneliti pada populasi atau sampel tertentu, pengambilan data dilakukan dengan menyebarkan kuesioner dengan populasi nya yaitu pengguna aktif Traveloka di seluruh Indonesia. Kuesioner disebarkan dengan menggunakan skala Likert dan data yang diperoleh berupa data ordinal. Pengolahan data menggunakan analisis regresi linear berganda. Jumlah sampel yang dikumpulkan sebanyak 272 responden mengacu kepada tabel sampling Isaac and Michael (1981).

\section{Kerangka Pemikiran}

Keputusan pembelian konsumen diharapkan mampu untuk mengembangkan potensi jual beli pasar elektronik (e-commerce) di Indonesia pada marketplace. Penggunaan marketplace menjadi salah satu pemilihan saluran distribusi, saat ini banyak beragam marketplace online yang sudah sangat berkembang. E-Service Quality dan E-Promotion menjadi hal yang paling penting dalam kegiatan bisnis pada marketplace online. Berikut merupakan kerangka pemikiran dari penelitian ini. 


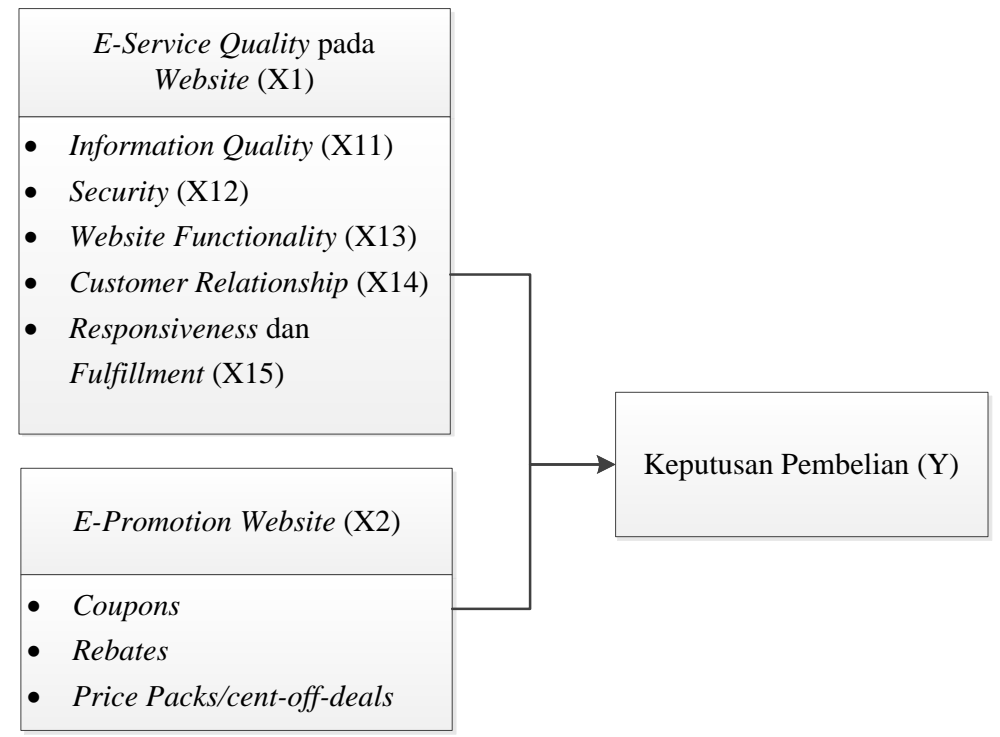

Gambar 5 Kerangka Pemikiran

\section{HASIL PENELITIAN DAN PEMBAHASAN}

Berdasarkan hasil uji validitas dan uji reliabilitas diketahui bahwa hasil kuesioner yang dikumpulkan mempunyai pernyataan yang valid dan reliable sehingga bisa memudahkan dalam melakukan pengolahan data ke tahapan berikutnya. Selanjutnya, dilakukan uji asumsi klasik yaitu uji normalitas data dan uji multikolinearitas.

\section{Uji Normalitas Data}

Uji normalitas bertujuan untuk melihat apakah nilai residual terdistribusi normal atau tidak. Model regresi yang baik adalah memiliki nilai residual yang terdistribusi normal. Uji normalitas dapat dilakukan dengan uji Kolmogorov Smirnov. Apabila nilai signifikansi > 0,05, maka nilai residual berdistribusi normal. Apabila nilai signifikansi $<0,05$, maka nilai residual tidak berdistribusi normal. Hasil pengujian normalitas dapat dilihat pada tabel sebagai berikut:
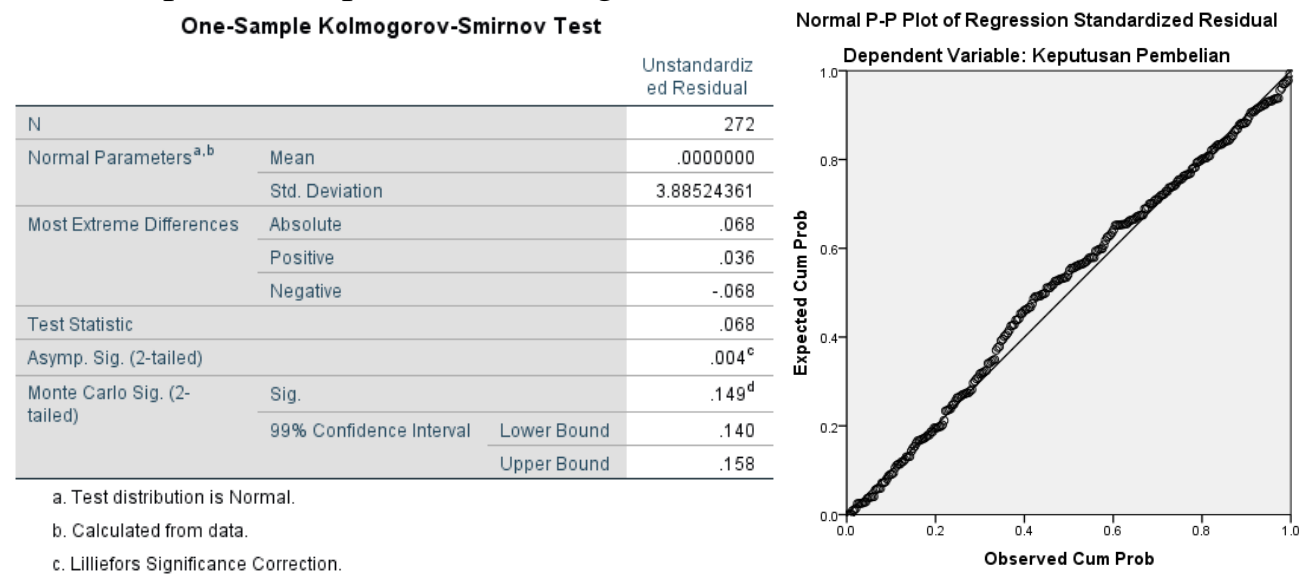


\section{Gambar 6 Uji Normalitas}

Berdasarkan hasil uji normalitas data diatas dapat disimpulkan bahwa nilai sig $>0,05$ yaitu sebesar 0,149 serta berdasarkan gambar 7 bahwa titik-titik ploting yang terdapat pada gambar "Normal P-P Plot of Regression Standardized Residual" selalu mengikuti dan mendekati garis diagonalnya. Oleh karena itu sebagaimana dasar atau pedoman pengambilan keputusan dalam uji normalitas teknik probability plot dapat disimpulkan bahwa nilai residual berdistribusi normal.

\section{Uji Multikolinearitas}

Uji multikolinearitas diperlukan untuk menguji apakah model regresi ditemukan adanya korelasi (hubungan kuat) antar variabel bebas atau variabel independen. Apabila hasil nilai uji Variance Inflation Factor (VIF) $\leq 10,00$ maka tidak terjadi multikolinearitas dan apabila hasil uji nilai Tolerance $\geq 0,10$ maka tidak terjadi multikolinearitas. Berikut merupakan hasil pengujian multikolinearitas :

Tabel 2 Uji Multikolinearitas

\begin{tabular}{|c|c|c|c|c|c|c|c|c|}
\hline \multirow[b]{2}{*}{ Mode } & & \multicolumn{2}{|c|}{ Unstandardized Coefficients } & \multirow{2}{*}{$\begin{array}{c}\text { Standardized } \\
\text { Coefficients } \\
\text { Beta } \\
\end{array}$} & \multirow[b]{2}{*}{$\mathrm{t}$} & \multirow[b]{2}{*}{ Sig. } & \multicolumn{2}{|c|}{ Collinearity Statistics } \\
\hline & & B & Std. Error & & & & Tolerance & VIF \\
\hline \multirow[t]{3}{*}{1} & (Constant) & 23.553 & 2.374 & & 9.923 & .000 & & \\
\hline & E-Service Quality Website & 289 & .056 & .293 & 5.118 & .000 & .866 & 1.155 \\
\hline & E-Promotion Website & .374 & .072 & .296 & 5.171 & .000 & .866 & 1.155 \\
\hline
\end{tabular}

a. Dependent Variable: Keputusan Pembelian

Berdasarkan hasil uji normalitas data diatas menunjukkan bahwa nilai tolerance dari kedua variabel sama yaitu 0,866 yang artinya $\geq 0,10$ maka tidak terjadi multikolinearitas, sedangkan untuk nilai VIF dari kedua variabel sama yaitu 1,155 yang artinya $\leq 10,00$ maka tidak terjadi multikolinearitas. Sehingga dapat disimpulkan bahwa kedua variabel independen tersebut tidak terjadi multikolinearitas.

\section{Koefisien Determinasi $\left(\mathbf{R}^{2}\right)$}

Bertujuan untuk mengukur seberapa jauh kemampuan variabel independen ( $e$ service quality website dan e-promotion website) dalam menjelaskan variasi variabel dependen (keputusan pembelian). Nilai koefisien determinasi adalah nol dan satu. Nilai yang mendekati satu berarti adalah variabel independen memberikan hampir semua informasi yang dibutuhkan untuk memprediksi variabel dependen (Ghozali, 2011) dalam Dita Puspita (2016). Berikut merupakan hasil dari uji koefisien determinasi $\left(\mathrm{R}^{2}\right)$.

Tabel 3 Uji Koefisien Determinasi $\left(\mathbf{R}^{2}\right)$

\begin{tabular}{ll|r|r|r} 
Model & $\mathrm{R}$ & R Square & \multicolumn{1}{c}{$\begin{array}{c}\text { Adjusted R } \\
\text { Square }\end{array}$} & $\begin{array}{c}\text { Std. Error of } \\
\text { the Estimate }\end{array}$ \\
\hline 1 & $.487^{\mathrm{a}}$ & .237 & .231 & 3.900 \\
\hline
\end{tabular}

a. Predictors: (Constant), E-Promotion Website, E-Service Quality Website 
Berdasarkan hasil diatas, dapat dilihat bahwa nilai $R$ Square dari analisis ini menunjukkan nilai 0,237 yang berarti bahwa variabel independen (e-service quality website dan e-promotion website) hanya dapat menjelaskan sebesar $23.7 \%$ terhadap variabel dependen yaitu keputusan pembelian, sedangkan sisanya $76.3 \%$ dijelaskan oleh variabel lain yang tidak disertakan dalam model ini.

\section{Analisis Regresi Linear Berganda}

Teknik analisis data yang digunakan pada penelitian ini adalah teknik analisis regresi dua predictor atau analisis berganda. Analisis ini digunakan untuk mengetahui ada tidaknya pengaruh e-service quality website (X1) dan e-promotion website (X2) secara bersama-sama terhadap keputusan pembelian (Y) pada pelanggan online travel agent khususnya Traveloka.

\section{Tabel 4 Analisis Regresi Linear Berganda}

\begin{tabular}{|c|c|c|c|c|}
\hline \multirow[b]{2}{*}{ Mode } & & \multicolumn{2}{|c|}{ Unstandardized Coefficients } & \multirow{2}{*}{$\begin{array}{c}\text { Standardized } \\
\text { Coefficients } \\
\text { Beta }\end{array}$} \\
\hline & & $\mathrm{B}$ & Std. Error & \\
\hline \multirow[t]{3}{*}{1} & (Constant) & 23.553 & 2.374 & \\
\hline & E-Service Quality Website & .289 & .056 & .293 \\
\hline & E-Promotion Website & .374 & .072 & .296 \\
\hline
\end{tabular}

a. Dependent Variable: Keputusan Pembelian

Berdasarkan hasil diatas, dapat disimpulkan bahwa seluruh variabel independen yaitu $e$-service quality website dan e-promotion website memiliki nilai korelasi atau hubungan yang positif. Hal ini menunjukkan bahwa $e$-service quality website dan $e$ promotion website dapat menciptakan fluktuasi pada keputusan pembelian.

\section{Uji Hipotesis}

Uji T

Menurut Ghozali (2011) dalam Dita Puspita (2016), penerapan uji t ini bertujuan untuk mengetahui pengaruh antara variabel independen terhadap variabel dependen secara parsial. Pengujian ini dilakukan dengan melihat besarnya nilai signifikan. Jika nilai sig lebih kecil $(<)$ 0,05, maka variabel independen mempengaruhi variabel dependen serta dengan ketentuan yaitu jika nilai Thitung > nilai Ttabel, maka Ho ditolak dan menerima Ha. Berikut adalah hasil dari uji hipotesis dengan uji parsial (uji t) 


\begin{tabular}{|c|c|c|c|c|c|c|}
\hline \multirow[b]{3}{*}{ Model } & \multicolumn{6}{|c|}{ Tabel 5 Uji T } \\
\hline & & \multicolumn{2}{|c|}{ Unstandardized Coefficients } & \multirow{2}{*}{$\begin{array}{c}\text { Standardized } \\
\text { Coefficients } \\
\text { Beta }\end{array}$} & \multirow[b]{2}{*}{$t$} & \multirow[b]{2}{*}{ Sig. } \\
\hline & & $\mathrm{B}$ & Std. Error & & & \\
\hline \multirow[t]{3}{*}{1} & (Constant) & 23.553 & 2.374 & & 9.923 & .000 \\
\hline & E-Service Quality Website & .289 & .056 & .293 & 5.118 & .000 \\
\hline & E-Promotion Website & .374 & .072 & .296 & 5.171 & .000 \\
\hline
\end{tabular}

a. Dependent Variable: Keputusan Pembelian

Berdasarkan hasil dari tabel diatas menunjukkan bahwa thitung untuk e-service quality website sebesar 5,118 sedangkan untuk e-promotion website 5,171. Nilai $\mathrm{t}$ hitung yang dihasilkan $>\mathrm{t}$ tabel $(1,968)$, serta nilai sig yaitu $0,000<0,05$, maka bisa disimpulkan bahwa terdapat pengaruh dua variabel independen terhadap variabel dependen yaitu keputusan pembelian secara parsial.

\section{Uji F}

Menurut Ghozali (2012) dalam Sekar Arum (2019), uji statistik F pada dasarnya menunjukkan apakah semua variabel independen atau variabel bebas yang dimasukkan dalam model mempunyai pengaruh secara bersama-sama terhadap variabel dependen atau variabel terikat. Pengujian ini dilakukan dengan melihat besarnya nilai signifikan. Jika nilai sig lebih kecil $(<) 0,05$, maka variabel independen mempengaruhi variabel dependen serta dengan ketentuan yaitu jika nilai Fhitung > nilai Ftabel, maka Ho ditolak dan menerima Ha. Berikut merupakan hasil dari uji hipotesis dengan uji simultan (uji F):

\begin{tabular}{|c|c|c|c|c|c|c|}
\hline \multirow[b]{2}{*}{ Model } & \multicolumn{6}{|c|}{ Tabel 6 Uji F } \\
\hline & & $\begin{array}{l}\text { Sum of } \\
\text { Squares }\end{array}$ & df & Mean Square & $\mathrm{F}$ & Sig. \\
\hline \multirow[t]{3}{*}{1} & Regression & 1269.131 & 2 & 634.566 & 41.728 & $.000^{\mathrm{b}}$ \\
\hline & Residual & 4090.777 & 269 & 15.207 & & \\
\hline & Total & 5359.908 & 271 & & & \\
\hline
\end{tabular}

a. Dependent Variable: Keputusan Pembelian

b. Predictors: (Constant), E-Promotion Website, E-Service Quality Website

Berdasarkan hasil dari tabel diatas menunjukkan bahwa $\mathrm{F}$ hitung untuk $e$ service quality website dan e-promotion website sebesar 41,728. Maka bisa disimpulkan bahwa terdapat pengaruh pada dua variabel independen secara bersamaan (simultan) terhadap variabel dependen yaitu keputusan pembelian.

\section{KESIMPULAN}

Berdasarkan hasil analisis pengujian hipotesis, dapat ditarik kesimpulan bahwa e-service quality dan e-promotion website secara parsial maupun simultan berpengaruh terhadap keputusan pembelian pada pengguna layanan Traveloka. Hubungan ini ditemukan berpengaruh secara positif dan signifikan. Besar pengaruh e-service quality website, dan e-promotion website terhadap keputusan pembelian di Traveloka adalah 
23\%. Sedangkan sisanya dipengaruhi oleh variabel yang tidak termasuk dalam penelitian ini. Secara praktis, Online Travel Agent (OTA) khususnya Traveloka perlu untuk mempertimbangkan e-service quality serta e-promotion pada website mereka di Indonesia. kedua variabel tersebut dianggap penting dan berpengaruh termhadap keputusan pembelian konsumen. Secara akademisi, penelitian ini dapat dikembangkan lebih jauh dengan memasukan objek lainnya yaitu aplikasi mobile. Penelitian ini masih terbatas pada website Traveloka saja belum membahas aplikasi mobile-nya. Penggunaan aplikasi mobile Traveloka sudah umum sehingga perlu dikaji apakah variabel e-service quality dan e-promotion tetap berpengaruh atau tidak.

\section{REFERENSI}

Anggraeni, Penia \& Putu Rina Madiawati. (2016). Pengaruh Kepercayaan dan Kualitas Informasi terhadap Keputusan Pembelian Secara Online pada Situs www.traveloka.com; Jurnal e-Proceeding of Management: Vol.3, No.2 Agustus 2016.

Aprilia Pratiwi, Hildha. (2018). Pengaruh Kualitas Pelayanan, Harga, dan Promosi terhadap Kepuasan Pelanggan Traveloka di Yogyakarta, Juli 2018. Fakultas Ekonomi Universitas Negeri Yogyakarta.

Arum, R, Sekar. (2019). Pengaruh Personal Selling terhadap Keputusan Pembelian (Studi Kasus Pada Layanan Trucking PT Iron Bird Logistics), Agustus 2019. Politeknik Pos Indonesia Bandung.

Hendriyati, Lutfi. (2019). Pengaruh Online Travel Agent terhadap Pemesanan Kamar di Hotel Mutiara Malioboro Yogyakarta; Jurnal Media Wisata, Volume 17, Nomor 1, Mei 2019. https://osf.io/e3st8/download/?format=pdf

Pramudita, A. S. (2019). Pengukuran performa digital distribution channel terhadap keputusan pembelian hostel pada Pinisi Backpacker dengan multinomial logistic regression. Competitive, 14(2), 1-8.

Pramudita, A. S., Yanuar, A., \& Hilman, T. (2019). BUSINESS MODEL FORMULATION FOR E-NEWSPAPER IN INDONESIA ( CASE STUDY: PIKIRAN RAKYAT ). Jurnal Bisnis Dan Manajemen, 20(1), 15-31. https://doi.org/http://dx.doi.org/10.24198/jbm.v20i1.250

Puspita Sari, Dita. (2016). Pengaruh Iklan, Harga, dan E-Service Quality terhadap Repurchase Intention pada Pengguna Online Travel Agent Traveloka, Mei 2016. Fakultas Ekonomi dan Bisnis Universitas Islam Negeri Syarif Hidayatullah, Jakarta.

SimilarWeb. (2020). Website testing on Traveloka.com. https://www.similarweb.com/website/traveloka.com/

We are social and Hootsuite. (2020). Digital 2020 April Global Statshot Report. https://wearesocial.com/blog/2020/04/digital-around-the-world-in-april-2020

Widowati, Hari. (2019). Indonesia Jadi Negara dengan Pertumbuhan E-Commerce Tercepat di Dunia. https://databoks.katadata.co.id/datapublish/2019/04/25/indonesia-jadi-negara dengan-pertumbuhan-e-commerce-tercepat-di-dunia 